\title{
Sustainability Balanced Scorecards and their Architectures: Irrelevant or Misunderstood?
}

\author{
Erik G. Hansen ${ }^{1} \cdot$ Stefan Schaltegger ${ }^{2}$
}

Received: 21 September 2016/Accepted: 3 April 2017/Published online: 19 April 2017

(C) The Author(s) 2017. This article is an open access publication

\begin{abstract}
In a recent systematic review of the Sustainability Balanced Scorecard (SBSC) literature in this journal, we developed a typology of architectures as a basis for the process of SBSC design, implementation, use, and evolution. This paper addresses a comment by Hahn and Figge (2016) designed to stimulate further research. We argue that the existing literature demonstrates that the SBSC management tool can play an important role in corporate sustainability. The SBSC architectures-as representations of goals and priorities-form an integral and iterative part of the corporate sustainability strategy-making process and therefore cannot be isolated from it. However, the concept as such should not be overloaded (e.g. as a tool for radical change). In this paper, we first reflect on the potentials and constraints of the SBSC in relation to (1) radical or transformational change and (2) measuring performance outcomes on the level of humanearth systems. Second, we discuss the importance of SBSC architecture concerning (1) how it enables the integration of sustainability into business organisations; (2) how both strictly hierarchical cause-and-effect chains and less hierarchical designs can allow companies to seek inclusive profits; and (3) the contingency-based use of generic
\end{abstract}

Erik G. Hansen

erik.hansen@jku.at

Stefan Schaltegger

schaltegger@uni.leuphana.de

1 Institute for Integrated Quality Design (IQD), Johannes Kepler University (JKU) Linz, Altenberger Str. 69, 4040 Linz, Austria

2 Centre for Sustainability Management (CSM), Leuphana University Lüneburg, Scharnhorststr. 1, 21335 Lüneburg, Germany architectures (i.e. using the sustainability strategy and value system to determine a fitting architecture) in contrast to its use as a diagnostic tool (i.e. the architecture revealing the sustainability strategy and value system).

Keywords Balanced scorecard · Corporate sustainability · Corporate social responsibility · CSR - Strategy maps . Objective function - Integrative view - Performance measurement · Performance management · Management control $\cdot$ Trade-offs

\section{Introduction}

Rising awareness about the limitations of measuring organisational success only with financial metrics has spurred interest in multidimensional performance measurement and management systems such as the balanced scorecard (BSC) (Maltz et al. 2003; Brignall and Modell 2000; Searcy 2012). Moreover, the increasing strategic importance of environmental, social, and ethical aspects and related performance metrics have inspired debates about extensions and alterations to the BSC, sometimes referred to as the Sustainability Balanced Scorecard (SBSC) (Figge et al. 2002).

A systematic review of the field (Hansen and Schaltegger 2016), as well as reactions from the field, demonstrates that research on the SBSC is in a sandwich position: On the one hand, mainstream strategists such as Kaplan and Norton (2001), the originators of the BSC, argue that if the concept was further developed to address multiple stakeholder goals, it would no longer be a balanced scorecard, but instead a "stakeholder scorecard". This view is supported by Jensen (2002), who questions the value of any corporate objective function with more than one 
(economic) goal to maximise, as this would jeopardise the economic success of the firm. On the other hand, some sustainability scholars argue that the BSC-whether with incrementally or radically redesigned architectures-will never be able to make an important contribution to sustainable development (Hahn and Figge 2016).

However, it is this sandwich space-between strategy researchers prohibiting any changes in the "original" version and sustainability scholars finding changes to be futile-where fruitful research is emerging (e.g. Sundin et al. 2010; van der Woerd and van den Brink 2004; DiasSardinha et al. 2002). While the critique of the strategy camp has been addressed in our original review, this paper focuses on the critique by Hahn and Figge (2016) from within the corporate sustainability field. Their main line of argument is that (1) the SBSC is unable to address transformational change towards sustainability and (2) this holds true independent of the SBSC's architecture. Our response to this critique is that they overload the SBSC (and management systems more generally) with the expectation it should serve as an (independent) change agent towards radical sustainability transformation. Hahn and Figge's critique is a strawman argument. Our paper has a double aim: rebutting this idealistic critique and taking this rebuttal as basis to advance further ideas and research directions for theoretically sound improvements of corporate practice.

The remainder of this paper is structured as follows: In "Aims and scope of the SBSC (independent of architecture)" section, we first deal with the general scope of application and related limitations of the SBSC-independent of its architecture-in order to build realistic expectations regarding its role in corporate sustainability management. We particularly highlight the misunderstanding that the SBSC is an independent tool for transformational change and for mapping earthhuman system complexity. Section "The role of architecture for goal integration, relationships, and hierarchy" clarifies the role of SBSC architecture in three ways: how it enables the integration of sustainability into business organisations; how both the design decisions between strictly hierarchical causeand-effect chains and less hierarchical designs can allow companies to seek inclusive profits; and the typology of architecture usage as a contingency framework versus a diagnostic tool. Section "Conclusion" concludes the paper and spells out limitations.

\section{Aims and Scope of the SBSC (Independent of Architecture)}

The first part of this paper looks at the SBSC in general, independent from its architecture. We critically reflect on the desire of some to make the SBSC a vehicle for transformational change, to connect it with systems-level sustainability indicators, and to want it to map diverse management tensions, conflicts, and trade-offs.

\section{The SBSC as a Tool for Radical Change Towards Sustainability?}

\section{The SBSC as an Agent for Radical Change-a Strawman Argument}

To prevent false expectations about what the SBSC is capable of doing, it is important to be aware of the role of the balanced scorecard as a method and its limitations. Hahn and Figge's (2016) critique is largely based on a strawman argument. They wrongly state that we position the SBSC as a tool for the radical/transformational change of organisations-which we never meant to do-and then criticise the SBSC for not fulfilling this function. Clearly, Hahn and Figge overload the SBSC concept with expectations in a way that probably no measurement, management control, or accounting system could ever deliver, either in theory or in practice. Are material flow cost accounting, corporate sustainability reporting, or eco-design suitable tools for initiating radical change? Not necessarily, but they still play important roles in the overall sustainability management of organisations and in supporting management to create improvements (e.g. Jamali 2008; Bovea and Pérez-Belis 2012).

It is neither the performance management nor the accounting system that determines radical change, but the strategy-making which precedes the design (and use) of these systems, a principle generally referred to as "structure follows strategy" (Chandler 1962, p. 14). While radical change is crucial to achieving sustainable development, it is not the task of an SBSC or any other management control system to initiate this change (though such systems can indeed have an impact on the organisational culture; Länsiluoto and Järvenpää 2010; Simons 1994). The function of an SBSC is to support strategy implementation. The kind of strategy an SBSC supports depends on the kind of strategy in place beforehand. Hence, the SBSC is generally not a tool to trigger radical corporate transformation but, if that is the strategy, it could serve as a method to help implement aspects of transformation. Many other approaches are much better suited to analyse and initiate radical change in companies (see Table 1), such as business model innovations for sustainability (Schaltegger et al. 2016a; b; Boons and LüdekeFreund 2013; Stubbs and Cocklin 2008), sustainable entrepreneurship (e.g. Hockerts and Wüstenhagen 2010; Schaltegger and Wagner 2011), and sustainability-oriented innovation (Hansen et al. 2009; Hall 2002; Adams et al. 2012; Paech 2007). 
Table 1 Selected approaches addressing radical sustainability innovation and transformation in, of, and with organisations

\begin{tabular}{|c|c|c|}
\hline Approach & Description & Authors \\
\hline $\begin{array}{l}\text { Backcasting and the natural } \\
\text { step framework }\end{array}$ & $\begin{array}{l}\text { Backcasting from basic principles for sustainability is an } \\
\text { approach looking at a final state of sustainability as a long- } \\
\text { term goal and then looking at the necessary operative steps } \\
\text { of a unit (e.g. organisation) to reach this goal. This is } \\
\text { different from the common business strategy of incremental } \\
\text { improvement without a clearly defined final goal. This } \\
\text { approach also covers a method for sustainable product } \\
\text { development which takes a radical service orientation and } \\
\text { questions traditional product sales and which overall } \\
\text { "encourages and aids development of products that support } \\
\text { society's transformation towards sustainability" (Byggeth } \\
\text { et al. 2007) }\end{array}$ & $\begin{array}{l}\text { Holmberg and Robèrt (2000), Robèrt (2000) and } \\
\text { Byggeth et al. (2007) }\end{array}$ \\
\hline $\begin{array}{l}\text { Sustainable } \\
\text { entrepreneurship }\end{array}$ & $\begin{array}{l}\text { Sustainable entrepreneurship looks at entrepreneurs in small } \\
\text { ventures and how they develop radically more sustainable } \\
\text { products and services, with which they challenge current } \\
\text { market practices. It also covers the responses by incumbents } \\
\text { and how they integrate sustainability into their product } \\
\text { portfolio in the mass market. In addition to studying } \\
\text { individual actors, their roles, and contributions to } \\
\text { transformation, the concept also covers co-evolutionary } \\
\text { processes emerging from these activities }\end{array}$ & $\begin{array}{l}\text { Hockerts and Wüstenhagen (2010), Schaltegger } \\
\text { and Wagner (2011), Schaltegger (2002) and } \\
\text { Wüstenhagen (1998) }\end{array}$ \\
\hline $\begin{array}{l}\text { Sustainability-oriented } \\
\text { innovation (SOI) }\end{array}$ & $\begin{array}{l}\text { Sustainability-oriented innovation is an approach that looks at } \\
\text { sustainability transformation within companies, with a } \\
\text { focus on the product and service portfolio. It is based on the } \\
\text { assumption that companies cannot significantly contribute } \\
\text { to sustainability if they do not make their products } \\
\text { sustainable. Though starting with basic life-cycle } \\
\text { improvements on the product design level, the concept also } \\
\text { covers the level of product-service systems and business } \\
\text { models that inspire innovation in solutions rather than mere } \\
\text { product sales }\end{array}$ & $\begin{array}{l}\text { Paech (2007), Hansen et al. (2009) and Adams } \\
\text { et al. (2012) }\end{array}$ \\
\hline $\begin{array}{l}\text { Business models for } \\
\text { sustainability (BMfS) }\end{array}$ & $\begin{array}{l}\text { Business model research has become a trend in conventional } \\
\text { (strategic) management research. Sustainability scholars } \\
\text { adopted the business model perspective because it allows } \\
\text { them to explain how companies can overcome barriers } \\
\text { against implementing sustainability improvements when } \\
\text { they go against the existing business model as represented } \\
\text { by the value proposition, infrastructure, customer } \\
\text { relationship and financial logic. Adapting or redeveloping } \\
\text { the business model to support sustainability make possible } \\
\text { changes in the organisation and product portfolio }\end{array}$ & $\begin{array}{l}\text { Lüdeke-Freund (2009), Boons and Lüdeke- } \\
\text { Freund (2013), Schaltegger et al. (2012) and } \\
\text { Schaltegger et al. (2016a) }\end{array}$ \\
\hline $\begin{array}{l}\text { Organisational } \\
\text { ambidexterity for driving } \\
\text { sustainability innovation }\end{array}$ & $\begin{array}{l}\text { Ambidexterity is about creating organisational structures and } \\
\text { processes for enabling companies to simultaneously pursue } \\
\text { two innovation modes that often conflict-incremental and } \\
\text { radical innovation. Recently, the ambidexterity concept has } \\
\text { been adopted by scholars in sustainability and innovation } \\
\text { research in order to analyse how conventional firms could } \\
\text { embark towards sustainability while also retaining their } \\
\text { existing core business }\end{array}$ & $\begin{array}{l}\text { Hahn et al. (2016), Seebode et al. (2012), Wicki } \\
\text { (2015) and Wicki et al. (2015) }\end{array}$ \\
\hline
\end{tabular}

Moreover, there is a blind spot in Hahn and Figge's critique of the SBSC and how it hinders radical transformational change. They forget that radical innovation (and the related transformation of industries and societies) is usually created in start-ups and small entrepreneurial firms (Hockerts and Wüstenhagen 2010). All these entities are commonly characterised by rather low formalisation and high flexibility, and therefore, they simply do not use extensive management control systems such as the BSC in the first place.

Even in the case of established organisations exploring radical sustainability-oriented innovation separated from the mainstream exploitative business (e.g. via corporate venturing units)—an "ambidextrous organizational 
design" we agree has huge prospects for sustainability (Hahn and Figge 2016; Hahn et al. 2016; Wicki et al. 2015; Wicki 2015)—linking the SBSC with such an independent radical innovation unit is simply misleading. In a setting of ambidexterity, exploitative and exploratory units differ with regard to structure, routines, styles, systems of reward and control, and resource allocation (Simsek et al. 2009). While the exploitative core business may have a management control system such as the SBSC in place, exploratory units responsible for radical innovation usually do not. From this perspective, the SBSC can neither facilitate nor hinder radical innovation - it is simply unrelated and therefore underlines our claim that Hahn and Figge's critique is aimed at a strawman.

\section{Implementing Radical Strategic Change with the SBSC: the Case of Transform}

Rejecting the claim that the SBSC itself can be an agent of radical change does not mean that the SBSC and related tools cannot play diverse roles in implementing radical change processes in organisations. If managers do indeed engage in radical strategic change through strategy development, business model transformation, or other entrepreneurial activities, then the SBSC can of course help them implement the new strategy.

Let us have a look at Transform, a small for-profit company in the Canadian food industry (Journeault 2016). The company sells convenience food such as prepared salads and pies to supermarkets and generates annual revenues of approximately 4 million dollars. It is vertically integrated in that it grows fruits and vegetables on its own fields. The company has recently faced various market, environmental, and policy challenges: consumer demand for healthier food, stricter food safety certification, and tougher wastewater discharge regulations. These challenges led Transform to adopt an ambitious sustainability strategy, including the introduction of stakeholder engagement practices, organic farming and an organiccertified product range, eco-improvement of the entire production process, as well as a training-based approach enabling workers to be employed from the local community:

In order to capture new market opportunities and to address these important strategic issues, Transform decided to review its current strategy [emphasis added] to integrate environmental and social considerations. (Journeault 2016, p. 223)

After the decision to undertake this quite remarkable change in strategy, the company operationalised the strategy with an SBSC. The SBSC shows for every single environmental and social measure in the strategy how the company contributes to sustainability, value creation, and economic performance (see Fig. 1): the training and employment of employees from local communities decrease employee turnover; organic farming practices (while costing money) improve worker health and attract the attention of environmentally aware customer groups; cleaner production techniques (e.g. wastewater) reduce cost and increase reputation in local communities, etc.

The visualisation of linkages between social and environmental practices, value creation, and ultimate economic success helps managers to better understand how sustainability is an integral part of their business operations and economic performance, and gain their support rather than opposition (Journeault 2016, p. 223).

\section{Do SBSCs Stabilise Existing Unsustainable Business Models and Practices?}

Hahn and Figge (2016) claim that the BSC would stabilise unsustainable business models and practices. This turns their prior argument on its head (i.e. that SBSCs would not be able to radically transform companies), and therefore, we will only briefly address it here. First, performance management systems do indeed increase the formalisation of an organisation and therefore to some extent also "stabilise" existing business practices. And it is indeed a recognised risk that, if applied too rigidly, the SBSC can become a barrier to change (van der Woerd and van den Brink 2004, p. 178). However, this critique is, again, rather general, as the introduction of any organisational structures, policies, systems, and processes deliberately increases the formalisation and hence stabilisation of the organisation. Therefore, this is nothing specific to the SBSC. However, as shown previously, even increased formalisation allows for strategy change, with adjustments made in subsequent structure-follows-strategy cycles.

\section{Can a (corporate) SBSC Address Systems-Level Outcomes?}

Related to the demand for radical transformation is the concern that corporate sustainability performance measurement and management tools, such as the SBSC, would be limited to the organisational level (e.g. corporate emissions) and therefore unable to contribute to measuring corporate contributions to sustainability outcomes at the systems or societal level (e.g. regarding planetary boundaries; cf. Whiteman et al. 2013). The question is whether these outcomes must be explicitly recognised in the architecture of an organisational management tool. Let us look at the example of a company creating eco-friendly production processes in its organisation and its entire supply chain. This of course has the goal of reducing the 


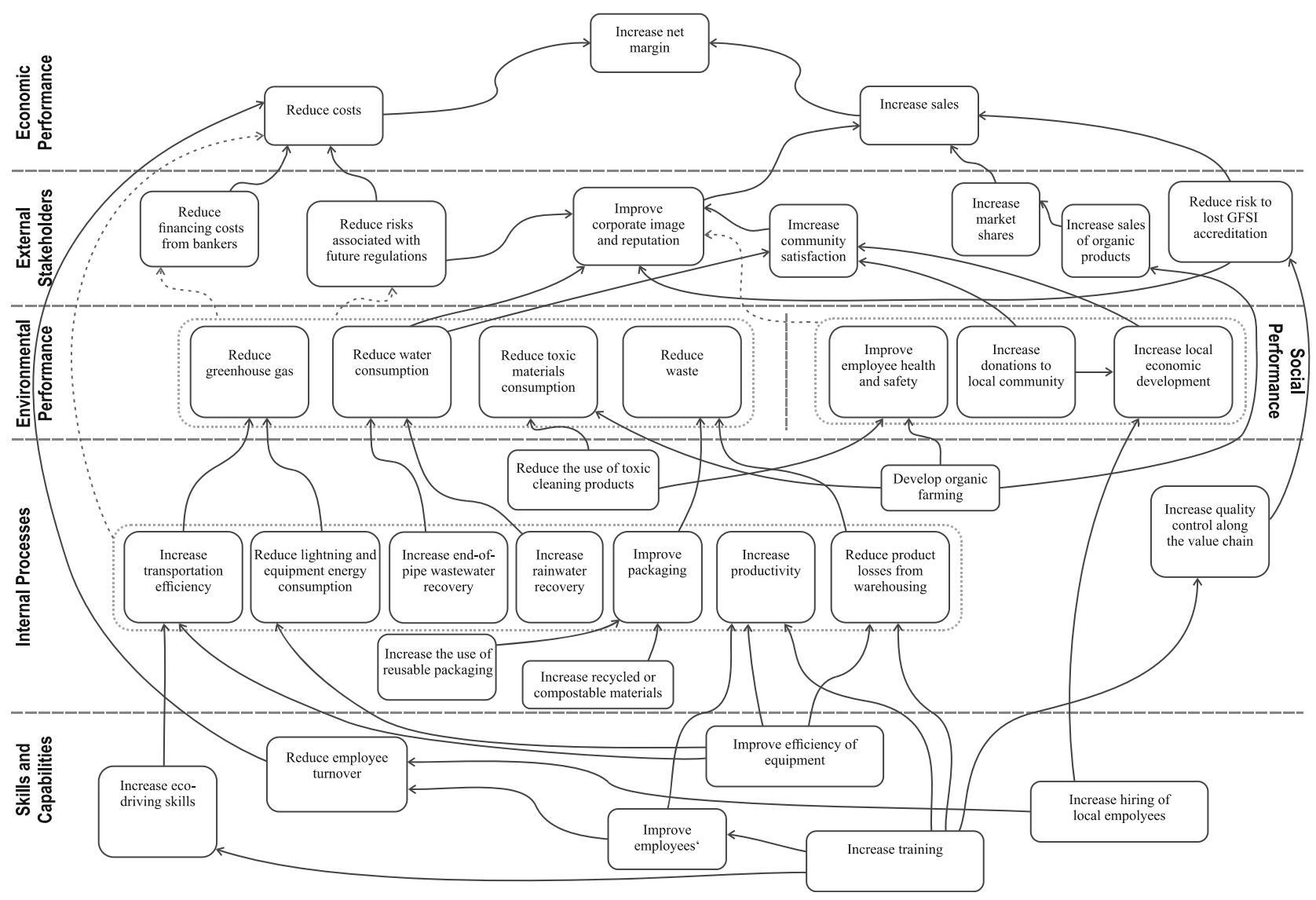

Fig. 1 An SBSC visualising the implementation of the new sustainability-based strategy and how new sustainable business lines (organic products) contribute to financial performance (Journeault 2016, p. 223)

impact of production on the natural environment (which is obviously external to the organisation). However, can and should this organisation measure global outcomes (e.g. species diversity or river water quality), rather than its own carbon emissions, wastewater discharges, and toxic wastes disposal (which reflect the impact contribution to a sustainability problem at the system or global level). And, if so, where should they be addressed in the SBSC? Should they be considered in a given SBSC perspective (e.g. environmental-friendly production processes in the internal process perspective) by assessing whether individual sustainability-related goals have been achieved, or should they be integrated in a single overriding goal at the top of hierarchical SBSCs (e.g. sustainable development instead of financial perspective)?

We are rather pessimistic about outcome measurement at the systems level. Measuring actual corporate impacts and outcomes at the level of the society, the economy, or the natural environment is, if possible at all, very complex and resource intense. A major problem is that a single organisation usually has only a limited impact on the economic, societal, and environmental system in which it is embedded. As Jennings and Zandbergen (1995, p. 1023) put it, "individual organisations simply contribute to the large system in which sustainability may or may not be achieved". Systems-level indicators that can be verifiably influenced in a major way by a single organisation are exceedingly rare. Looking again at the case of Transform can be rewarding. While the firm's own organic farms positively contribute to transforming the local ecosystem, this impact is limited because they do not have direct influence on the farming practices of neighbouring operations, which mostly apply conventional agro-industrial practices. Consequently, the company itself is unable to, for instance, regenerate the local drinking water system, stop global biodiversity loss, or reverse climate change because this depends on the farming practices of many other actors, too.

While corporate measurement and management tools such as the SBSC are not usually used to measure systemslevel sustainability problems, there are rare cases. In an action research project implementing an SBSC and related metrics, we witnessed such organisational efforts in the Thai subsidiary of a large international company in the chemical and pharmaceutical industry. Given the developing nation context, this company included the goal of 
"social contribution (to local communities in need)" into its non-market perspective of the SBSC (Hansen et al. 2010). They provided monetary donations to and volunteering activities in selected communities with the ultimate goal of improving living standards. The company then collaborated with a local NGO to measure goal achievement by implementing a measurement framework used in the international development aid community with a finegrained differentiation between inputs, activities, outputs, outcomes, and impacts (Hansen and Spitzeck 2011). A simplified version was implemented in the organisation and led to impact-level indicators on, for example, "\% of households with increased income" in an area where the company was sponsoring community development projects (see Table 2). The impact-level indicators were measured by the NGO and then reported to the company, as the company (as is often the case) did not have the expertise.

This example shows that the SBSC and related indicators can indeed be used to measure impacts at the societal level. As this is not an easy task and requires strong executive support, partnerships, and considerable investment, it is not surprising that only very few companies have pursued such objectives so far.

An alternative approach would be to measure a company's impact contribution to a systems-level sustainability problem by calculating its share compared to a sector, regional/national, or global average or benchmark. An example would be a company first measuring the greenhouse gases it emits in tonnes and then their potential global warming impact in $\mathrm{CO}_{2}$ equivalents. Based on this information, it could then calculate its impact on global warming compared to the industry average and finally set a benchmark for it to achieve a sustainable level of emissions. How the integration of such sustainability indicators into a management control system such as the SBSC could be achieved with positive impacts on a system level and on the organisation is a worthwhile area for future research.
Overall, while addressing systems-level outcomes can be a feasible and fruitful exercise for sustainability champions, most organisations will focus their attention on designing and implementing ambitious SBSC systems using organisational-level performance indicators that are related to the larger system in which the organisation is embedded.

\section{Tensions and Conflicts Between Different Sustainability Aspects and Their Representation in the SBSC Strategy Map}

Integrating social and environmental issues with economic ones in a strategy map does not show how conflicting relationships are handled in an SBSC. Hahn and Figge consider trade-offs between conflicting sustainability objectives to be at the core of corporate sustainability management (Hahn et al. 2010) and, in order to resolve trade-off dilemmas, demand that all corporate sustainability tools specify the "relationship of the different sustainability aspects among each other" (Hahn and Figge 2011, p. 328). They furthermore conclude that the SBSC is incapable of specifying these relationships because it is limited to linear cause-and-effect chains (Hahn and Figge 2016). We fully agree that trade-offs need to be studied by corporate sustainability researchers. However, resolving these trade-offs is the key challenge of sustainability managers. The strategy map of an SBSC is not the right place to address trade-offs in detail. First, pragmatic reasons exclude this, as it would lead to overly complex "drawings" (rather than "maps"), which though of interest to researchers, would likely be too complex and of little use for managers.

Second, and more importantly, the outcome of a strategic development approach and strategy implementation process should not be a comprehensive portrayal of management tensions and trade-offs. This complexity

Table 2 Example of societal impact indicators used for measuring goal achievement in a SBSC (based on Hansen and Spitzeck 2011, p. 420; see also: Hansen et al. 2010)

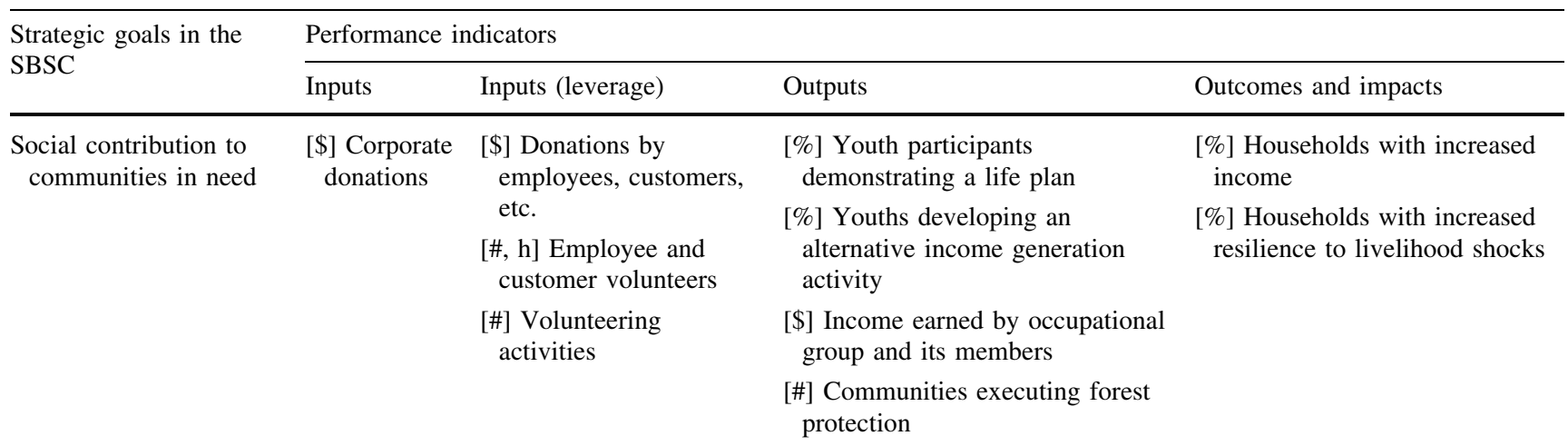


would not necessarily help to find solutions, and might indeed frustrate managers charged with executing sustainability strategy. Instead, what is needed is a simplified abstraction of reality with clear choices how an organisation can address its sustainability goals. In other words, the complexity of tensions and trade-offs must be addressed much earlier, already during the strategy-making process, and the resulting strategy map must show a clear path towards sustainable value creation processes. This strategymaking process must involve significant managerial efforts to clarify how to position the organisation with regard to difficult trade-offs. For example, retailers must decide how to position themselves in the dilemma between local sourcing and fair-trade products promoting international development (Holt and Watson 2008). Moreover, managers must invest in the development of solutions to overcome perceived trade-offs. For example, in the agriculture industry organic production standards are often perceived as a trade-off between environmental protection and crop productivity, even though advanced organic practices show that they can integrate both (Carvalho and Barbieri 2010). In both cases, we can observe that "a business case for sustainability has to be created-it does not just happen" (Schaltegger et al. 2012).

Third, as the result of a strategy-making process, a strategy map represents a narrative of how top management sees the organisation both as a competitor in the market and as an agent of sustainable development (Baker and Schaltegger 2015). This map portrays simplified relationships between individual objectives. Such a map may not always seem like a naturalistic representation of reality nor will it always be statistically validated (Sundin et al. 2010). It will be a mix of objective and subjective relationships influenced by managerial values, a vision of the future, and strategic intent, and could even be simply "symbolic and ceremonial" (cf. Brignall and Modell 2000, p. 294). Ultimately, a strategy map aims at relating a supportive story of the strategic vision, describing what the plan is, and detailing how it will be implemented. This effort should show how business and sustainability relate to each other, rather than irritate managers with overly complex schematic drawings of tensions and trade-offs. Going back to the Transform case, after thoughtful weighing of the pros (e.g. no toxic chemical inputs) and the cons (e.g. investment costs; potential productivity loss; loss of former customers), the SBSC may have helped management to decide that an organic product line was not only the right ethical choice, but also the best business decision. All of the complexity is in the process of making the right strategic decisions, and the actual SBSC contains only a simple linear relationship from "developing organic farming" to "increased sales".
Fourth, a strategy map is the result of a multitude of complex management processes reflecting a multitude of issues, both explicitly (i.e. the definition of objectives, main relationships, targets, actual measures) and implicitly (e.g. managerial understanding of the linkages between objectives; organisational culture; self-perception of what the organisation should be). Even if a strategy map still included (implicit) tensions or failed to portray all relationships, some degree of decision-making and problemsolving competence would be delegated to the manager of the individual unit. As empirical research on "balancing" shows (Sundin et al. 2010), managers are indeed able to do this.

Overall, we conclude that strategy maps are simplifications and therefore unlikely to incorporate detailed mappings of all imaginable tensions and trade-offs related to how corporations could potentially address ecosystem and social system complexity. Still, we do not exclude this possibility and find it an interesting subject for further research. Researchers could develop new types of strategy maps going beyond causal relationships and incorporate different types of relationships.

\section{The Role of Architecture for Goal Integration, Relationships, and Hierarchy}

While the prior section dealt with a general critique of the SBSC, this section examines the role of the SBSC architecture: its general importance, the integration of sustainability objectives into performance perspectives, different hierarchical designs, and its usefulness for assessing an organisation's sustainability orientation.

\section{A Primer on Architectures as Representations of Management Priorities—or the Fallacy of Imagining Buildings Without Architecture}

An architect designs a new building on different levels of abstraction so that not only are clients able to gain a deeper understanding of what is being built, but also the workers are able to build it. For example, the architecture reveals the number and kinds of rooms (kitchen, bath, living room, etc.) in a building. It is a structural representation of priorities (e.g. a large kitchen and a small bedroom) and by definition does not show how users ultimately interact with the architecture (in the sense of processes); for example, it does not say anything about how often and in which sequence people use the rooms in a building.

Just as a building's architecture shows priorities for different rooms through their size, SBSC architectures represent a company's different priorities concerning its 
economic, environmental, social, and other goals. Many proposals for SBSC architectures in the literature have different foci and do not elaborate on the interrelationship between different sustainability perspectives. However, to say that SBSC architectures are irrelevant (Hahn and Figge 2016) because they simply juxtapose objectives while neglecting interrelationships is simply wrong. It does not do justice to the breadth and depth (including conflicting views) of research in this developing field. Current SBSC literature addresses a wide range of stakeholders (e.g. Jamali 2008; Hubbard 2009) and acknowledges that they have different priorities depending on their values. Others discuss interrelationships between different sustainability issues and goals within and between the different SBSC performance perspectives (Bieker and Waxenberger 2002; Jamali 2008; Sundin et al. 2010; Epstein and Wisner 2001a, b). Finally, a number of researchers argue that an organisation's sustainability management efforts depend on and are constrained by the degree and nature of the BSC hierarchy (e.g. Dias-Sardinha et al. 2002; van Marrewijk 2004; van der Woerd and van den Brink 2004; Voelpel et al. 2006; SIGMA 2003; Dias-Sardinha et al. 2007).

Ultimately, we agree with Bedford et al. (2008, p. 33), who recommend that if a BSC system is flawed, then its architecture and design elements should be analysed rather than demonising the entire system.

\section{The Nature of Goal Representation in Performance Perspectives: Add-on Versus Integration}

One central role of the SBSC architecture is to determine how to integrate sustainability-related goals into individual performance perspectives (and how this resonates with the sustainability strategy). There are a number of different approaches: supplementation with a dedicated perspective, integration into a single or multiple perspective(s), and combination of integration and add-on elements in an "extended" perspective. The continuum from reactive to proactive strategy, which we have linked to these integration alternatives (Hansen and Schaltegger 2016, p. 211), is of course only a generic framework as each actual case is different. It is very likely that outliers can be found that seem to contradict this continuum model. However, Hahn and Figge's (2016) critique that no general link exists between integration options and corporate sustainability strategy is too simplistic. They reject the strategy continuum and argue that only an add-on perspective will advance radical sustainability. They claim that sustainability transformation - and the bottom-up organisational initiatives it entails-requires flexibility if it is to support innovation and that such flexibility is not given in the core perspectives of the SBSC. They conclude that only add-on perspectives (e.g. non-market) provide an innovation space for radical sustainability transformation.

Hahn and Figge then take the hypothetical example of a cement company aiming to engage proactively with a key sustainability issue, biodiversity, and argue that the company would need the flexibility of an additional SBSC perspective to integrate this issue as a strategic objective. However, this example is completely misleading. First, it shows that the authors fail to achieve their own goal of providing an integrative perspective of corporate sustainability. In an integrative perspective of embedded systems (Marcus et al. 2010), business is understood as part of the economy, just as the economy is part of society, which in turn is embedded in the natural environment. Hence, a comprehensive understanding of the sustainability impact of a company's operations (internal processes) requires considering local communities (among other stakeholders) and the natural environment (including biodiversity) in which value creation is embedded. That is also what recent standards for environmental management systems expect from organisations by requiring the application of "lifecycle thinking" (ISO 2015). From this perspective, it is self-evident that biodiversity issues are at the core of a cement company's value chain because cement production is based on "the extraction of raw materials from the earth's crust" requiring the "removal of soil and changes in topography", which ultimately leads to "impacts on the surrounding natural and social environment" (CSI 2011, p. 1). It is therefore a core responsibility of cement companies to create rehabilitation plans before starting mining operations (CSI 2011; Schaltegger and Beständig 2010) or to replace mining activities by recycling and other circular activities.

A comprehensive analysis of the SBSC's internal process perspective representing the value chain or the full product life-cycle helps an organisation not only to understand the general links between the value creation processes and their environmental and social impacts, but also the economic relevance of environmental and social issues. For example, more careful mining operations might reduce subsequent costs for rehabilitation and improve the organisation's local and global reputation. Against this background, it becomes evident that a cement factory needs to integrate biodiversity issues into the SBSC's internal process perspective. Treating this exclusively in an add-on perspective, separate from internal processes, shows an understanding of sustainability issues as detached from the core business (as in the case with corporate philanthropy activities, for instance). Furthermore, if necessary, an add-on perspective can easily be created in combination with the goal integration into existing perspectives, an "extended" design we consider to be the most proactive strategy (Hansen and Schaltegger 2016, p. 205). 
In stark contrast to Hahn and Figge's (2016) claim that the SBSC framework is rigid, we conclude (as can be seen in the internal process perspective) that the SBSC has great flexibility in designing performance perspectives.

\section{Critique of Linear Cause-and-Effect Relationships and Systematic Subordination of Environmental and Social Objectives Under Economic Outcomes}

Hahn and Figge (2016) stress the inherent weakness of linear cause-and-effect chains, which they believe necessarily subordinate sustainability objectives to economic ones. This critique is well established in the literature and therefore has already been addressed in our review that consequently also explored nonlinear architectures (Hansen and Schaltegger 2016). However, Hahn and Figge's critique is once again too simplistic for reasons we now present.

\section{False Expectation that the SBSC Architecture must Mirror Earth-Human System Complexities}

We agree that it is questionable that strict cause-and-effect chains-understood in a narrow sense-can fully explain organisational realities (Brignall 2002), and they are probably ineffective when referring to the systems level because sustainability problems are characterised as complex, wicked, intertwined, and multifaceted (Wiek et al. 2012; Schaltegger et al. 2013; Scholz 2011). However, using the simple equation of "biophysical and ecosystem complexity is nonlinear" vs. "SBSC is linear" to reject any sustainability management system based on linear relationships is misleading.

As argued above, system complexity needs to be addressed as part of the strategy-making process before implementing a strategy and therefore before drawing a strategy map. The (linear) relationships visualised in the map do not describe complexity; they show how strategy deals with complexity and potentially also resolves dilemmas. These relationships are furthermore not naturalistic or statistically validated relationships; they are rooted in extensive internal and external analysis and are an expression of managerial values and strategic intent.

\section{More Recent SBSC Architectures Mostly Ignored}

There is no doubt that some SBSC designs, in particular earlier models (e.g. Figge et al. 2002), are based solely on strict cause-and-effect chains and a strict hierarchy with social and environmental measures subordinate to a toplevel economic objective. However, the SBSC literature has developed different SBSC approaches, some of which are non-hierarchical and others that prioritise non- economic objectives. Though empirical evidence is so far rather limited (Hansen and Schaltegger 2016, p. 207; Hahn and Figge 2016), at least conceptually many newer architectures are "satisficing" designs, aiming to "ensure an outcome that is at least minimally satisfactory along all dimensions" (Sundin et al. 2010, p. 208). These designs pursue multiple objectives simultaneously, such as the triple-bottom line (van Marrewijk 2004, p. 152; Dias-Sardinha et al. 2002), or have flat network-like designs that treat environmental and societal objectives as equally important to established economic objectives (e.g. Bieker and Waxenberger 2002; Hubbard 2009; Voelpel et al. 2006). The intention of these SBSC architectures is to prevent environmental and social management from being instrumentalised for economic purposes. These models, some of them deviating radically from established BSC architectures, aim for achieving sustainability goals and not maximising financial profits. None of them subordinates social and environmental issues to economic goals.

Based on such evidence, we introduced a new dimension to SBSC architectures reflecting their different approaches to goal hierarchy (and related cause-and-effect chains or logical interrelationships): hierarchical, semi-hierarchical, and flat (non-hierarchical) architectures (Hansen and Schaltegger 2016). Unlike Hahn and Figge (2016), we are confident that these approaches to SBSC hierarchy give much more flexibility to organisations with different ambition levels for sustainability. Our original review argued that architectures going beyond conventional hierarchy hold a greater potential for radical innovation towards sustainability (Hansen and Schaltegger 2016, p. 213):

This is best explained by outlining the risks involved for organisations in sticking to a strictly hierarchical BSC architecture (van Veen Dirks and Wijn 2002). If management works with a too narrow focus using a limited number of finance-related indicators (e.g. energy savings), sustainability may be marginalised as environmental and social contributions to shortterm financial success. Too rigid performance management tools, as represented by the strictly hierarchical SBSC, make it difficult for companies to adapt their product-market mix towards sustainability (van der Woerd and van den Brink 2004, p. 178), “endanger the survival of the firm in the innovation economy" (Voelpel et al. 2006, p. 49) and impede company managers from effectively responding to disruptive environmental changes (Christensen 1997; Christensen and Bower 1996). Innovation and change are, however, necessary to maintain and increase competitiveness in future markets characterised by such disruptive changes and transitions as from fossil 
to low carbon energy; from combustion and purely private mobility to electric vehicles and shared mobility systems; as well as from conventional consumption goods to environmentally friendly and fairtrade products (e.g. Geels 2012; Penna and Geels 2012). Such strategic renewal, as opposed to operational optimisation, requires long-term investments without an ultimate guarantee of success. Even though Kaplan and Norton's original conception of the BSC's learning and growth perspective was intended to provide space for such learning processes, it may be very difficult to realise this potential in a hierarchy dominated by top-level financial goals. In contrast, semi-hierarchical BSCs may foster the incorporation of a 'future dimension' into performance measurement systems (Maltz et al. 2003, p. 191) and thus enable ambidextrous organisations with the capability to simultaneously manage incremental and radical change processes within the same organisation (Tushman and O'Reilly 1996; Raisch et al. 2009).

Transcending hierarchy with semi-hierarchical or even flat architectures often allows an organisation to overcome the subordination of environmental and social goals to economic ones. With multiple top-level goals, such architectures reflect-at least to a certain degree-the higher complexity of the social and ecological systems an organisation is embedded in.

\section{Revisiting the Strictly Hierarchical Architecture: How Integration Enables Sustainability Transformation Despite Linearity}

While we have just highlighted how unorthodox SBSC architectures can support sustainability management, it is now necessary to revisit conventional hierarchical architectures in the light of Hahn and Figge's claim that the linear nature of the SBSC, with profit maximisation as an end-point, hinders sustainability management. More specifically, we pose the question: Is profit as a top-level objective generally an obstacle or even counterproductive to sustainability? A bit more provocatively we might ask "Is profit evil?" This question is particularly important as we are talking about "for-profit" firms (which are obviously not the same as non-profit organisations focusing on providing, for example, common goods, because they cannot sustain losses over longer timespans and are expected and designed to generate financial returns to shareholder investments). This is a strong justification for such an architecture, whether the profit principle is interpreted literally or, as Brignall and Modell (2000, p. 294) find, it is also "ceremonial". We think that this is not an either/or issue. One extreme is the corporation that uses its pursuit of profits as a reason to subordinate and marginalise sustainability objectives. In this case, the linear cause-andeffect chains resulting in profits would indeed pose a threat to sustainability. The other extreme is a company founded by an entrepreneur with a sustainability mission, who as part of the transition to becoming an established organisation implements the SBSC to improve organisational formalisation and efficiency (e.g. Schneider and Vieira 2010). In this case, the top-level profit goal is not only not an obstacle it actually helps the organisation grow and diffuse sustainability into markets (Hockerts and Wüstenhagen 2010; Schaltegger and Wagner 2011).

Reality is usually more nuanced than these extreme cases. The actual role of the top-level profit goal in a hierarchical design must be judged against the level of sustainability integration in the value creation of the organisation and its representation in various performance perspectives of the SBSC. With such a "proactive strategy", even a strict hierarchy can support sustainability transformation. For example, the Transform case study (Journeault 2016) shows that (1) the extended internal process perspective addressing the switch to organic farming practices and (2) the revised customer perspective addressing organic-certified product lines for new customer groups demonstrate together how sustainability-oriented innovation based on product life-cycle considerations can change the source of profits (cf. Hansen et al. 2009). In this way, environmental and social sustainability are integrated broadly into SBSC performance perspectives and become a motor for further diffusion of sustainable products in the market. This takes market share from competing products that are less sustainable and thereby contributes to sustainability-oriented market transformations (Hockerts and Wüstenhagen 2010; Schaltegger and Wagner 2011). The successful commercialisation of slow fashion, renewable energy, and other sustainable products or technologies in niche markets show the crossindustry relevance of the SBSC, regardless of whether the organisations have a sustainability mission (e.g. Chouinard and Brown 1997) or, as in the case of Transform, they are established organisations diversifying into such markets. ${ }^{1}$ Regardless of the type of SBSC hierarchy, implementing the SBSC in sustainability-driven companies can contribute to the professionalisation of the organisation, enabling them to achieve a greater market impact and ultimately taking market share away from competitors with less sustainable products. In such a case, seeking profits is aligned with advancing sustainability.

\footnotetext{
1 And-with reference to the cement industry discussed above-it does not exclude the possibility of a cement company with radically more sustainable business practices (e.g. offering circular cement based solely on recycled resources, instead of engaging in mining operations).
} 
In conclusion, generic SBSC architectures can be representative of both elements in Hahn and Figge (2011)'s dichotomy of "inclusive profitability", in which profits are made from products integrating economic, social and environmental objectives, and "bounded instrumentality", in which social and environmental issues are addressed only insofar as they contribute to the profitability of conventional business processes. Consequently, profit per se is not "evil". It does not necessarily hinder sustainability; it is unsustainable products, services, and value creation processes used to maximise profit (and often the reluctance to change or replace these) that causes sustainability problems. The holistic integration of sustainability with its representation in SBSC performance perspectives, with internal processes at the core, is hence nothing other than what Hahn and Figge call an "integrative view of corporate sustainability" (2016) with a goal of "inclusive profits" (2011). An internal process (and related customer) perspective from a comprehensive product life-cycle (Ny et al. 2006) and supply chain management perspective (Harms et al. 2013; Beske et al. 2015) leads to a much more integral understanding of the SBSC than in its original form (Figge et al. 2002) and provides significant sustainability potential even in the case of profitoriented architectures. Consequently, the sustainability of products and related internal (value creation) processes have to be analysed in detail in order to determine whether a company pursues inclusive profitability or bounded instrumentality, and what additional role the SBSC hierarchy plays in driving sustainability.

Having said this, some industries or businesses, despite attempts to address sustainability concerns along different performance perspectives, have such large inherent sustainability problems that it is admittedly unrealistic to think such an integrative view can be achieved. Take the example of nuclear energy technology, for which there is no absolute safety from accidents and misuse, and therefore remains an unsustainable technology despite industry attempts to position it otherwise (cf. Garud et al. 2010). ${ }^{2}$

\section{The role of the SBSC architecture for diagnosing sustainability orientation}

\section{Outside-in vs. inside-out}

One key result of our review of the SBSC literature is the development of a two-dimensional typology linking SBSC

\footnotetext{
${ }^{2}$ It is interesting to note that current US environmental measures to tackle climate change include the replacement of coal by nuclear power due to its relatively low $\mathrm{CO}_{2}$ emissions. However, despite significant efforts by the industry to associate such positive benefits with the technology, taking a broader sustainability perspective it is highly debatable whether nuclear energy technology can be considered beneficial for sustainable development (cf. Garud et al. 2010).
}

architectures to value systems and corporate sustainability strategies (Hansen and Schaltegger 2016). Hahn and Figge (2016) claim the architecture of an organisation does not reflect organisational progress towards sustainability (as specified through the two dimensions "value system" and "sustainability strategy"). Their critique is based on an understanding of the typology of SBSC architectures as a diagnostic tool following an inside-out logic, with the organisation's SBSC design (the inner part of the typology) determining or diagnosing the organisation's sustainability strategy and value system (the outer two dimensions of the typology).

This is, however, not its intended use. Though in principle this approach could work in many cases, it can also be strongly misleading. As put forward in our original article, the typology should be used as an outside-in contingency framework (Hansen and Schaltegger 2016, p. 214). Following such a contingency approach (cf. Chenhall 2003; Husted 2000), organisations choose an appropriate SBSC design based on pre-existing or new organisational variables, here represented by the sustainability strategy and the value system. From this perspective, the typology is a guide for strategy implementation. ${ }^{3}$

\section{The role of theoretical perspectives in interpreting SBSC architecture}

While our contingency framework gives organisations clear guidance on how to best choose an appropriate SBSC architecture, many SBSC designs in practice today may have been derived from other approaches. Moreover, real SBSC architectures do not necessarily represent actual practice in organisations as the three theoretical perspectives-instrumental, social/political and normativedemonstrate (Hansen and Schaltegger 2016, p. 204):

These ... theoretical perspectives ... are important to understand the potential roles of the SBSC for organisations and to better understand the main differences in SBSC architectures.

To identify the true aims of organisations implementing the SBSC, it is the researcher's task to choose the theoretical perspective that best supports the analysis. We have stressed in the original review that all three theoretical perspectives can be used to study SBSC architectures.

However, it is important to emphasise here that all SBSC architectures-regardless of value system and related hierarchy-can be grounded in all three

\footnotetext{
${ }^{3}$ Readers of the original article will have seen the section with practical implications, where we give clear guidelines on use: cf. Hansen and Schaltegger (2016, p. 215).
} 
theoretical perspectives. (Hansen and Schaltegger 2016, p. 209)

While some organisations implement SBSC architectures with the instrumental goal of furthering strategic sustainability goals, others are only seeking external legitimacy and may have no intention of changing internal practices. By developing an institutional perspective on multidimensional performance management systems, Brignall and Modell (2000) find that when stakeholder groups exert considerable pressure on organisations, they tend to decouple individual performance measures, performance dimensions, or hierarchical levels and thereby "maintain the myth that it is possible to simultaneously comply with several conflicting interests" (p. 299). We have followed this insight and conclude that organisations may also adopt different SBSC architectures to comply with pressure from external stakeholder groups, while maintaining internal flexibility through decoupling (Hansen and Schaltegger 2016, p. 213; see also: Schaltegger and Hörisch 2015).

Even if an SBSC has been implemented for instrumental reasons - i.e. with the goal of driving sustainability - the actual practice at various management levels can differ from the original objective if individual managers act on the basis of their own values and mental frames (Bento et al. 2016). ${ }^{4}$ Therefore, it bears repeating that the typology

\footnotetext{
$\overline{4}$ The results of Bento et al.'s (2016) experimental study show, to some extent, that the technical integration of sustainability-related objectives in SBSC architecture may not always prevent financial bias. While the authors imply there is a general bias in the SBSC (even if it was implemented for instrumental reasons), we see the study rather as a proof of legitimacy seeking by the top management as a response to institutional pressures, with managers on the lower levels (the study participants) being pressured to decouple (Hansen and Schaltegger (2016). Bento et al. themselves address one major limitation of their study: the SBSC architecture in their experiment was limited to an add-on perspective (architecture "A0" in our SBSC typology), which we have described as being prone to use as a marketing exercise or for philanthropic purposes. Presenting study participants with an SBSC architecture in a one-dimensional table with a list of objectives per perspective (see Table 1 in Bento et al. 2016)—without a strategy map-will most likely make it difficult for them to understand the strategic relevance of sustainability/CSR, which may have ultimately led to a decoupling strategy. We therefore support Bento et al.'s call for replication of their research using more advanced SBSC architectures, but would also like to emphasise the need for using strategy maps (not only tables with lists of objectives) in experiments in order to emphasise the interlinkage and integration that is fundamental to the SBSC. Another weakness of the study is that the experiments did not take place in a real managerial and organizational context, but were conducted with mixed set of students and other participants in artificial context. This limits the ability of participants to perceive the complex explicit and implicit incentives for sustainability embedded in an organizational culture.
}

of architectures is not primarily a diagnostic tool. Whether organisational or individual factors are responsible for a mismatch between SBSC structure and practices, this hints towards important ethical concerns in the design, implementation, and use of management control systems that should be investigated by further research.

\section{Contingencies, Fit and Misfit in the Use of the Typology of SBSC Architectures}

As discussed above, the typology of SBSC architectures provides a contingency framework for selecting the right architecture. It does not serve as a diagnostic tool to determine an organisation's stage of corporate sustainability development as expressed in the sustainability strategy and value system. In addition to instrumental applications, there may also be legitimacy-seeking SBSC implementations that decouple the architecture from the sustainability strategy and value system. Generally, Fig. 2 demonstrates the various patterns of misfit between an SBSC architecture of an organisation and the contingency factors sustainability strategy and organisational value system:

- b1: The SBSC architecture is less advanced than the current organisational value system. In this case, the potential for sustainability integration using less hierarchical SBSC designs is not fully utilised.

- b2: The SBSC architecture is more advanced than the current value system. Strict hierarchical SBSC designs are replaced by less hierarchical versions, although the organisation's value system is still profit oriented.

- c1: The SBSC architecture is less proactive than the current sustainability strategy.

- c2: The SBSC architecture is more proactive than the current sustainability strategy.

- d: Strong mismatch of corporate strategy (SBSC architecture) and contingency factors.

The source of misfit can be either intended or unintended. For example, in an instrumental perspective, b2 and c2 could be the intended consequence of organisational change efforts using BSC systems as levers for strategic renewal (Simons 1994) to advance, though with a time lag, to a higher-level sustainability strategy or value system.

In a social/political perspective, it may also be that the organisation has intentionally decoupled its SBSC architecture from current practice as an external legitimacyseeking strategy. Given the complex relationships between architecture and actual organisational practice as well as the high relevance legitimacy plays in corporate sustainability management practices (Schaltegger and Hörisch 2015; Aragón-Correa et al. 2016), these different cases of misfit should also be explored in future research from the 
Fig. 2 SBSC architecture fit with two contingency factors value system and sustainability strategy (based on Hansen and Schaltegger 2016, p. 205)

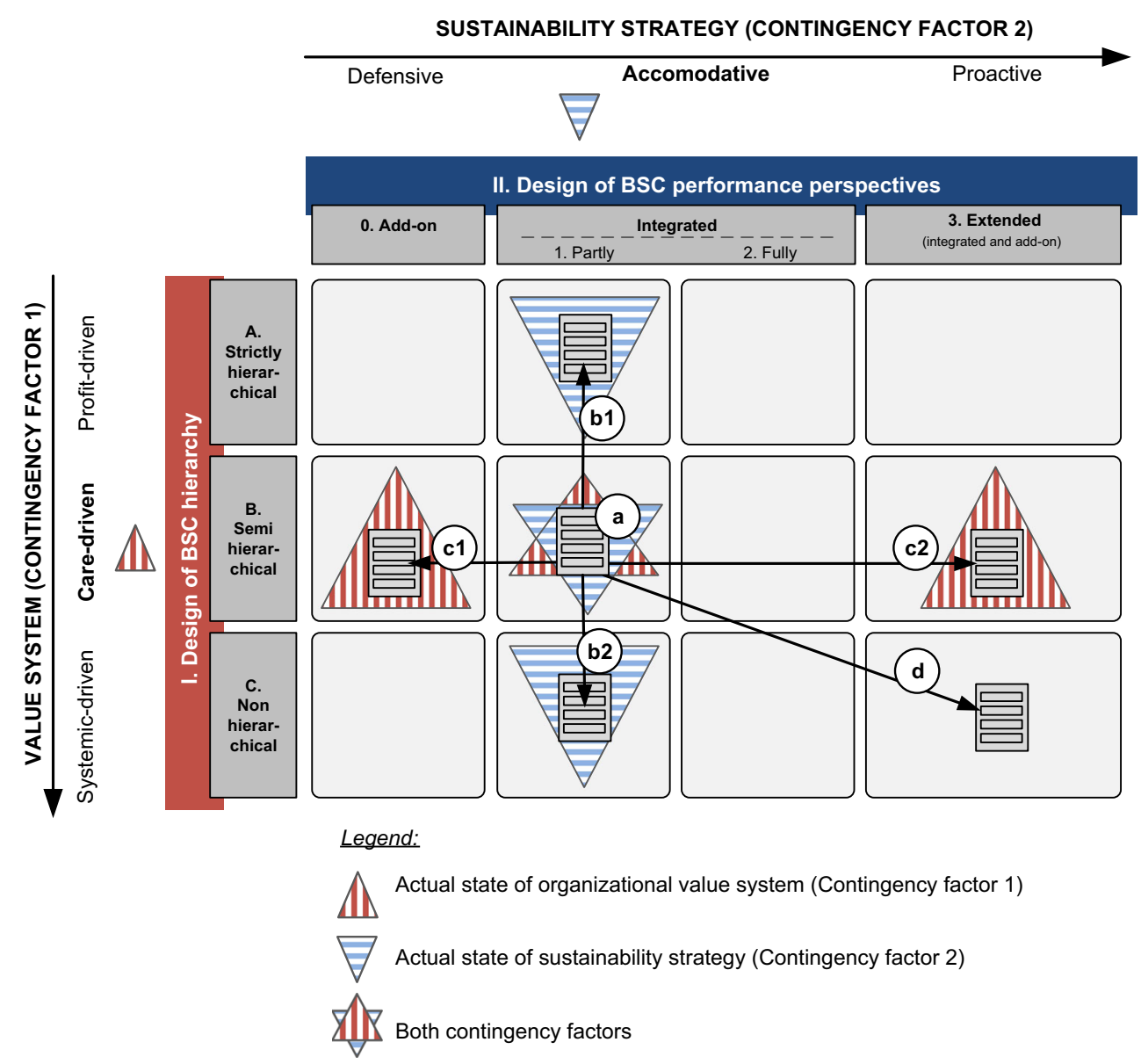

SBSC architecture/strategy map used by organization

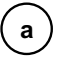

Fit of SBSC architecture with contingency factors

(b) (c) perspective of both instrumental and social/political theories.

\section{Conclusion}

We conclude that most SBSC approaches do not support radical organisational change or transformation-nor are they usually able to bridge exploitative and exploratory units in ambidextrous organisations. The concept should therefore not be overloaded with such claims or demands. We should also refrain from making bold assumptions that may be true for some but not all of the SBSC tools proposed in the literature. Most importantly, diverse developments in the SBSC literature show that alternative architectures are possible to a hierarchical architecture where all organisational goals are aligned towards profits.
Semi-hierarchical architectures allow the co-existence of several top goals (with all their tensions and contradictions) and flat hierarchies represent designs where no single goal predominates. However, SBSC architecture as a representation of the management priorities and views underlying an SBSC cannot serve as an independent strategy tool. The SBSC is not a replacement for management setting priorities for sustainability or developing a strategy for corporate sustainability. Depending on whether the design and use of the SBSC is based on an incremental or radical strategising process, it can, however, support the integration of sustainability into strategy implementation. Last but not least, BSC control systems can also serve as levers of strategic renewal. There are diverse iterative effects between strategy-making and control systems so that fruitful insights can be expected from further longitudinal research on strategy-making and implementation with the 
SBSC. In sum, the SBSC is one approach in a wide range of sustainability management tools, each with different strengths and weaknesses, and their effectiveness depends on the strategy behind them, how they are designed, and how they are combined and implemented.

Our conclusion should be considered with the limitations of our investigation in mind: First, the discussion of the SBSC architectures, based on our original systematic review, is indeed still ongoing, as there is still little empirical evidence for the effectiveness of unorthodox architectures. However, one of the purposes of a systematic review is to identify blank spots in the research field and encourage researchers to study these spaces. Hence, we have to be patient to see how research and practice develop in this regard. Second, many of the issues discussed here relate not only to the SBSC, but to the broader category of multidimensional performance management and measurement systems such as the performance prism (Neely 2005), Simon's (1994) levers of control or Malmi and Brown's (2008) packages of control. We therefore emphasise the importance of taking this discussion to a higher level and examining the SBSC as just one of many other "tools" with the potential to advance corporate sustainability.

Acknowledgements Open access funding provided by Johannes Kepler University Linz. We are thankful for the valuable discussions with and advice by Professor Roger Burritt (not only for this response article, but also concerning the previously published systematic review).

\section{Compliance with Ethical Standards}

Conflict of interest Author Erik G. Hansen declares that he has no conflict of interest. Author Stefan Schaltegger declares that he has no conflict of interest.

Ethical Approval This article does not contain any studies with human participants or animals performed by any of the authors.

Open Access This article is distributed under the terms of the Creative Commons Attribution 4.0 International License (http://crea tivecommons.org/licenses/by/4.0/), which permits unrestricted use, distribution, and reproduction in any medium, provided you give appropriate credit to the original author(s) and the source, provide a link to the Creative Commons license, and indicate if changes were made.

\section{References}

Adams, R., Jeanrenaud, S., Bessant, J. R., Overy, P., \& Denyer, D. (2012). Innovation for sustainability: A systematic review of the body of knowledge. London/Montreal, Canada. Retrieved 21 Mar 2013. http://nbs.net/wp-content/uploads/NBS-SystematicReview-Innovation.pdf. Accessed 21 March 2013.

Aragón-Correa, A. J., Marcus, A. A., \& Hurtado-Torres, N. (2016). The natural environmental strategies of international firms: Old controversies and new evidence on performance and disclosure.
Academy of Management Perspectives, 30(1), 24-39. doi:10. 5465/amp.2014.0043.

Baker, M., \& Schaltegger, S. (2015). Pragmatism and new directions in social and environmental accountability research. Accounting, Auditing \& Accountability Journal, 28(2), 263-294. doi:10. 1108/AAAJ-08-2012-01079.

Bedford, D., Brown, D. A., Malmi, T., \& Sivabalan, P. (2008). Balanced scorecard design and performance impacts: Some Australian evidence. Journal of Applied Management Accounting Research, 6(2), 17-36.

Bento, R. F., Mertins, L., \& White, L. F. (2016). Ideology and the balanced scorecard: An empirical exploration of the tension between shareholder value maximization and corporate social responsibility. Journal of Business Ethics, 70(1), 401. doi:10. 1007/s10551-016-3053-6.

Bieker, T., \& Waxenberger, B. (2002). Sustainability balanced scorecard and business ethics: Developing a balanced scorecard for integrity management. In Working Paper, 11 th Conference of the "Greening of Industry Network", 1 June 2002. Retrieved 16 July 2007. http://www.alexandria.unisg.ch/publications/person/ W/Bernhard_Waxenberger/17766. Accessed 16 July 2007.

Boons, F., \& Lüdeke-Freund, F. (2013). Business models for sustainable innovation: State-of-the-art and steps towards a research agenda. Journal of Cleaner Production, 45, 9-19. doi:10.1016/j.jclepro.2012.07.007.

Bovea, M., \& Pérez-Belis, V. (2012). A taxonomy of ecodesign tools for integrating environmental requirements into the product design process. Journal of Cleaner Production, 20(1), 61-71. doi:10.1016/j.jclepro.2011.07.012.

Brignall, S. (2002). The unbalanced scorecard: A social and environmental critique. In A. Neely, A. Walters, \& R. Austin (Eds.), PMA conference proceedings-Performance measurement and management 2002: Research and action: Cranfield School of Management, 2002 (pp. 85-92). Boston, MA: Performance Management Association.

Brignall, S., \& Modell, S. (2000). An institutional perspective on performance measurement and management in the 'new public sector'. Management Accounting Research, 11(3), 281-306. doi:10.1006/mare.2000.0136.

Byggeth, S., Broman, G., \& Robèrt, K.-H. (2007). A method for sustainable product development based on a modular system of guiding questions. Journal of Cleaner Production, 15(1), 1-11. doi:10.1016/j.jclepro.2006.02.007.

Carvalho, A. P., \& Barbieri, J. C. (2010). Innovation for sustainability: Overcoming the productivity of the sugar-and-ethanol industry's conventional system. Journal of Technology Management \& Innovation, 5(4), 83-94. doi:10.4067/S071827242010000400007.

Cement Sustainability Initiative (CSI). (2011). Guidelines on quarry rehabilitation: Biodiversity and land stewardship. Retrieved 29 Aug 2016. http://wbcsdcement.org/pdf/CSI\%20Guidelines\% 20on\%20Quarry\%20Rehabilitation\%20(English)_Dec\%202011. pdf.

Chandler, A. D., Jr. (1962). Strategy and structure: Chapters in the history of the American industrial enterprise. Washington, DC: Beard Books.

Chenhall, R. H. (2003). Management control systems design within its organizational context: Findings from contingency-based research and directions for the future. Accounting, Organizations and Society, 28(2-3), 127-168. doi:10.1016/S03613682(01)00027-7.

Chouinard, Y., \& Brown, M. S. (1997). Going organic: Converting Patagonia's cotton product line. Journal of Industrial Ecology, 1(1), 117-129. doi:10.1162/jiec.1997.1.1.117. 
Christensen, C. M. (1997). The innovator's dilemma: When new technologies cause great firms to fail. Boston, Mass: Harvard Business School Press.

Christensen, C. M., \& Bower, J. L. (1996). Customer power, strategic investment, and the failure of leading firms. Strategic Management Journal, 17, 197-218.

Dias-Sardinha, I., Reijnders, L., \& Antunes, P. (2002). From environmental performance evaluation to eco-efficiency and sustainability balanced scorecards. Environmental Quality Management, 12(2), 51-64. doi:10.1002/tqem.10063.

Dias-Sardinha, I., Reijnders, L., \& Antunes, P. (2007). Developing sustainability balanced scorecards for environmental services: A study of three large Portuguese companies. Environmental Quality Management, 16(4), 13-34. doi:10.1002/tqem.20139.

Epstein, M. J., \& Wisner, P. S. (2001a). Good neighbors: Implementing social and environmental strategies with the BSC. Balanced Scorecard Report 3(3). Reprint Number B0105C. Cambridge MA: Harvard Business School.

Epstein, M. J., \& Wisner, P. S. (2001b). Using a balanced scorecard to implement sustainability. Environmental Quality Management, 11(2), 1-10.

Figge, F., Hahn, T., Schaltegger, S., \& Wagner, M. (2002). The sustainability balanced scorecard-Linking sustainability management to business strategy. Business Strategy and the Environment, 11(5), 269-284.

Garud, R., Gehman, J., \& Karnoe, P. (2010). Categorization by association: nuclear technology and emission-free electricity. Institutions and Entrepreneurship Research in the Sociology of Work, 21, 51-93.

Geels, F. W. (2012). A socio-technical analysis of low-carbon transitions: Introducing the multi-level perspective into transport studies. Journal of Transport Geography, 24, 471-482. doi:10. 1016/j.jtrangeo.2012.01.021.

Hahn, T., \& Figge, F. (2011). Beyond the bounded instrumentality in current corporate sustainability research: Toward an inclusive notion of profitability. Journal of Business Ethics, 104(3), 325-345. doi:10.1007/s10551-011-0911-0.

Hahn, T., Figge, F., Pinkse, J., \& Preuss, L. (2010). Trade-offs in corporate sustainability: You can't have your cake and eat it. Business Strategy and the Environment, 19(4), 217-229. doi:10. 1002/bse.674.

Hahn, T., Pinkse, J., Preuss, L., \& Figge, F. (2016). Ambidexterity for corporate social performance. Organization Studies, 37(2), 213-235. doi:10.1177/0170840615604506.

Hahn, T., \& Figge, F. (2016). Why architecture does not matter: On the fallacy of sustainability balanced scorecards. Journal of Business Ethics. doi: 10.1007/s10551-016-3135-5.

Hall, J. K. (2002). Sustainable development innovation: A research agenda for the next 10 years. Journal of Cleaner Production, 10, 195-196.

Hansen, E. G., Große-Dunker, F., \& Reichwald, R. (2009). Sustainability innovation cube-A framework to evaluate sustainabilityoriented innovations. International Journal of Innovation Management, 13(4), 683-713. doi:10.1142/S1363919609002479.

Hansen, E. G., \& Schaltegger, S. (2016). The sustainability balanced scorecard: A systematic review of architectures. Journal of Business Ethics, 133(2), 193-221. doi:10.1007/s10551-0142340-3.

Hansen, E. G., Sextl, M., \& Reichwald, R. (2010). Managing strategic alliances through a community-enabled balanced scorecard: The case of Merck Ltd, Thailand. Business Strategy and the Environment, 19(6), 387-399. doi:10.1002/bse.689.

Hansen, E. G., \& Spitzeck, H. (2011). Measuring the impacts of NGO partnerships: The corporate and societal benefits of community involvement. Corporate Governance: International Journal of
Business in Society, 11(4), 415-426. doi:10.1108/ 14720701111159253.

Harms, D., Hansen, E. G., \& Schaltegger, S. (2013). Strategies in sustainable supply chain management: An empirical investigation of large German companies. Corporate Social Responsibility and Environmental Management, 20(4), 205-218. doi:10. $1002 /$ csr. 1293

Hockerts, K., \& Wüstenhagen, R. (2010). Greening Goliaths versus emerging Davids-Theorizing about the role of incumbents and new entrants in sustainable entrepreneurship. Journal of Business Venturing, 25(5), 481-492. doi:10.1016/j.jbusvent. 2009.07.005.

Holmberg, J., \& Robèrt, K.-H. (2000). Backcasting-a framework for strategic planning. International Journal of Sustainable Development and World Ecology, 7(4), 291-308. doi:10.1080/ 13504500009470049.

Holt, D., \& Watson, A. (2008). Exploring the dilemma of local sourcing versus international development-The case of the flower industry. Business Strategy and the Environment, 17(5), 318-329. doi:10.1002/bse.623.

Hubbard, G. (2009). Measuring organizational performance: Beyond the triple bottom line. Business Strategy and the Environment, $18,177-191$.

Husted, B. (2000). A contingency theory of corporate social performance. Business and Society, 39, 24-48.

International Standards Organization (ISO). (2015). Introduction to ISO 14001:2015. Geneva: ISO.

Jamali, D. (2008). A stakeholder approach to corporate social responsibility: A fresh perspective into theory and practice. Journal of Business Ethics, 82(1), 213-231. doi:10.1007/s10551007-9572-4.

Jennings, D. P., \& Zandbergen, P. A. (1995). Ecologically sustainable organizations: An institutional approach. Academy of Management Review, 20(4), 1015-1052.

Jensen, M. C. (2002). Value maximization, stakeholder theory, and the corporate objective function. Business Ethics Quarterly, $12(2), 235-256$.

Journeault, M. (2016). The integrated scorecard in support of corporate sustainability strategies. Journal of Environmental Management, 182, 214-229. doi:10.1016/j.jenvman.2016.07. 074.

Kaplan, R. S., \& Norton, D. P. (2001). The strategy-focused organization: How balanced scorecard companies thrive in the new business environment. Boston, Mass.: Harvard Business School Press.

Länsiluoto, A., \& Järvenpää, M. (2010). Greening the balanced scorecard. Business Horizons, 53(4), 385-395. doi:10.1016/j. bushor.2010.03.003.

Lüdeke-Freund, F. (2009). Business model concepts in corporate sustainability contexts: From rhetoric to a generic template for "Business Models for Sustainability". Lüneburg: Centre for Sustainability Management (CSM), Leuphana University of Lüneburg, Germany.

Malmi, T., \& Brown, D. A. (2008). Management control systems as a package-Opportunities, challenges and research directions. Management Accounting Research, 19(4), 287-300. doi:10. 1016/j.mar.2008.09.003.

Maltz, A. C., Shenhar, A. J., \& Reilly, R. R. (2003). Beyond the balanced scorecard: Refining the search for organizational success measures. Long Range Planning, 36(2), 187-204. doi:10.1016/S0024-6301(02)00165-6.

Marcus, J., Kurucz, E. C., \& Colbert, B. A. (2010). Conceptions of the business-society-nature interface: Implications for management scholarship. Business and Society, 49(3), 402-438. doi:10.1177/ 0007650310368827. 
Neely, A. (2005). The evolution of performance measurement research: Developments in the last decade and a research agenda for the next. International Journal of Operations \& Production Management, 25(12), 1264-1277. doi:10.1108/01443570510633648.

Ny, H., MacDonald, J. P., Broman, G., Yamamoto, R., \& Robèrt, K.H. (2006). Sustainability constraints as system boundaries: An approach to making life-cycle management strategic. Journal of Industrial Ecology, 10(1-2), 61-77. doi:10.1162/ 108819806775545349.

Paech, N. (2007). Directional certainty in sustainability-oriented innovation management. In M. Lehmann-Waffenschmidt (Ed.), Innovations towards sustainability: Conditions and consequences (pp. 121-140). Heidelberg, New York: Physica.

Penna, C. C., \& Geels, F. W. (2012). Multi-dimensional struggles in the greening of industry: A dialectic issue lifecycle model and case study. Technological Forecasting and Social Change, 79(6), 999-1020. doi:10.1016/j.techfore.2011.09.006.

Raisch, S., Birkinshaw, J., Probst, G., \& Tushman, M. L. (2009). Organizational ambidexterity: Balancing exploitation and exploration for sustained performance. Organization Science, 20(4), 685-695. doi:10.1287/orsc.1090.0428.

Robèrt, K.-H. (2000). Tools and concepts for sustainable development, how do they relate to a general framework for sustainable development, and to each other? Journal of Cleaner Production, 8(3), 243-254. doi:10.1016/S0959-6526(00)00011-1.

Schaltegger, S. (2002). A framework for ecopreneurship: Leading bioneers and environmental managers to ecopreneurship. Greener Management International, 38, 45-58.

Schaltegger, S., Beckmann, M., \& Hansen, E. G. (2013). Transdisciplinarity in corporate sustainability: Mapping the field. Business Strategy and the Environment, 22(4), 219-229. doi:10. 1002/bse. 1772

Schaltegger, S., \& Beständig, U. (2010). Corporate biodiversity management handbook. A guide for practical implementation. Berlin: Federal Ministry for the Environment and Nuclear Safety (BMBF) (Ed.), GTZ, \& CSM-Leuphana University Lüneburg.

Schaltegger, S., Hansen, E. G., \& Lüdeke-Freund, F. (2016a). Business models for sustainability: Origins, present research, and future avenues. Organization \& Environment, 29(1), 3-10. doi:10.1177/1086026615599806.

Schaltegger, S., \& Hörisch, J. (2015). In search of the dominant rationale in sustainability management: Legitimacy- or profitseeking? Journal of Business Ethics. doi:10.1007/s10551-0152854-3.

Schaltegger, S., Lüdeke-Freund, F., \& Hansen, E. G. (2012). Business cases for sustainability: The role of business model innovation for corporate sustainability. International Journal of Innovation and Sustainable Development, 6(2), 95-119. doi:10.1504/IJISD. 2012.046944.

Schaltegger, S., Lüdeke-Freund, F., \& Hansen, E. G. (2016b). Business models for sustainability: A co-evolutionary analysis of sustainable entrepreneurship, innovation, and transformation. Organization \& Environment, 29(3), 264-289. doi:10.1177/ 1086026616633272.

Schaltegger, S., \& Wagner, M. (2011). Sustainable entrepreneurship and sustainability innovation: Categories and interactions. Business Strategy and the Environment, 20(4), 222-237. doi:10. 1002/bse.682.

Schneider, R., \& Vieira, R. (2010). Insights from action research: Implementing the balanced scorecard at a wind-farm company. International Journal of Productivity and Performance Management, 59(5), 493-507. doi:10.1108/17410401011052904.

Scholz, R. W. (2011). Environmental problems, transdisciplinary research and managing sustainability transformations-The case of the energy system. Presentation given in Freiburg.
Searcy, C. (2012). Corporate sustainability performance measurement systems: A review and research agenda. Journal of Business Ethics, 107(3), 239-253. doi:10.1007/s10551-011-1038-z.

Seebode, D., Jeanrenaud, S., \& Bessant, J. (2012). Managing innovation for sustainability. $R \& D$ Management, 42(3), 195-206. doi:10.1111/j.1467-9310.2012.00678.x.

SIGMA. (2003). The SIGMA guidelines toolkit: Sustainability scorecard. London. Retrieved 21 July 2008. http://www. projectsigma.co.uk/Toolkit/SIGMASustainabilityScorecard.pdf. Accessed 21 July 2008.

Simons, R. (1994). How new top managers use control systems as levers of strategic renewal. Strategic Management Journal, 15(3), 169-189. doi:10.1002/smj.4250150301.

Simsek, Z., Heavey, C., Veiga, J. F., \& Souder, D. (2009). A typology for aligning organizational ambidexterity's conceptualizations, antecedents, and outcomes. Journal of Management Studies, 46(5), 864-894. doi:10.1111/j.1467-6486.2009.00841.x.

Stubbs, W., \& Cocklin, C. (2008). Conceptualizing a "Sustainability Business Model”. Organization \& Environment, 21(2), 103-127.

Sundin, H., Granlund, M., \& Brown, D. A. (2010). Balancing multiple competing objectives with a balanced scorecard. European Accounting Review, 19(2), 203-246. doi:10.1080/ 09638180903118736.

Tushman, M. L., \& O’Reilly, C. A. (1996). Ambidextrous organizations: Managing evolutionary and revolutionary change. California Management Review, 38(4), 8-30.

van der Woerd, F., \& van den Brink, T. W. M. (2004). Feasibility of a responsive business scorecard-A pilot study. Journal of Business Ethics, 55(2), 173-186.

van Marrewijk, M. (2004). A value BASED approach to organization types: Towards a coherent set of stakeholder-oriented management tools. Journal of Business Ethics, 55(2), 147-158. doi:10. 1007/s10551-004-1898-6.

van Veen Dirks, P., \& Wijn, M. (2002). Strategic control: Meshing critical success factors with the balanced scorecard. Long Range Planning, 35(4), 407-427. doi:10.1016/S0024-6301(02)00066-3.

Voelpel, S. C., Leibold, M., \& Eckhoff, R. A. (2006). The tyranny of the balanced scorecard in the innovation economy. Journal of Intellectual Capital, 7(1), 43-60. doi:10.1108/ 14691930610639769.

Whiteman, G., Walker, B., \& Perego, P. (2013). Planetary boundaries: Ecological foundations for corporate sustainability. Journal of Management Studies, 50(2), 307-336. doi:10.1111/j.14676486.2012.01073.x.

Wicki, S. (2015). Diversification through green innovations. $u w f$ UmweltWirtschaftsForum, 23(4), 197-203. doi:10.1007/s00550015-0370-7.

Wicki, S., Hansen, E. G., \& Schaltegger, S. (2015). Exploration of green technologies in SMEs: The role of ambidexterity, domain separation and commercialization. In E. Huizingh, S. Conn, M. Torkelli, \& I. Bitran (Eds.), XXVI ISPIM innovation conference, Budapest 14-17 June 2015. International Society for Professional Innovation Management.

Wiek, A., Ness, B., Schweizer-Ries, P., Brand, F. S., \& Farioli, F. (2012). From complex systems analysis to transformational change: A comparative appraisal of sustainability science projects. Sustainability Science, 7(S1), 5-24. doi:10.1007/ s11625-011-0148-y.

Wüstenhagen, R. (1998). Greening goliaths versus multiplying Davids: Pfade einer Coevolution ökologischer Massenmärkte und nachhaltiger Nischen. St. Gallen, Switzerland: IWÖ. 